\title{
The dilemmas of a gardener: discussing the arguments against language revitalisation
}

\section{A} ccording to an age-old metaphor used to distinguish between a prescriptive and descriptive study of language, a linguist has to choose between acting either as a "gardener", plucking out the "weeds" of unwanted forms, or a "botanist" observing and objectively analysing how the language is naturally used. While today's linguistics generally fall into the descriptive category, one particular field - endangered languages research - still promotes some of the "gardening" approach (Newman, 1998, pp. 11-14). However, instead of "weeding" the garden by imposing the use of one official language on the expense of smaller varieties, it encourages "fertilising" it to help the small and the vulnerable idioms survive. When it comes to endangered languages many people involved in fieldwork become engaged in a personal manner, partaking not only in the linguistic documentation but also working with the speech communities to help revitalise their ancestral tongues and stop the language from becoming obsolete (Harrison, 2007, p. 9).

While most of the opinions found in both popular and academic texts tend to sympathise with the revitalisation efforts, often creating a broader discourse of biolinguistic

\footnotetext{
1 Perhaps "pruning" fits the context better as a more invasive horticultural analogy. Prescriptive action needed to promote minority languages may be sometimes seen as controversial, because standarising the language may end up being counter-productive by excluding speakers who do not adhere to the artificially formed standard (see Lüpke, 2018).
} 
diversity (Maffi, 2005), there are those who stand on the opposing side of this issue. Arguments against language revitalisation, usually stated in an essayistic form rather than in academic papers ${ }^{2}$, are chiefly based on a common sense approach. Though at first glance they may appear convincing, they often lack the depth and rely on false premises or straw man fallacies. Such arguments, while sometimes commented in papers, are often automatically discarded by those emotionally involved in documenting and protecting the endangered languages as biased and inherently wrong. The point of this paper is to present and categorise the most common arguments against language revitalisation appearing in different polemical texts (opinion pieces and popular articles). They will be briefly discussed to consider which counterarguments can be easily dismissed, and which pose real challenges to face.

\section{Why play the devil's advocate?}

The fight to stop the mass extinction of world's languages has become a widely discussed issue, creating its own ideologies and ways of communicating with the public (Heller \& Duchêne, 2007). Researchers are often citing numerical data concerning the rapidness of language loss and the levels of endangerment. Supported by anecdotal examples of language variation and Whorfian relativism, they prove interesting for a wider audience. While it is almost universally agreed that diminishing linguistic diversity represents an irretrievable loss for all humanity ${ }^{3}$, the level of involvement in language maintenance stays debatable. Every endangered language and its speech community present a highly specific case of intricately woven factors, both linguistic and extralinguistic: cultural, political and historical. Therefore, it poses a problem far more nuanced than its simplified image presented by the mainstream media or even some generalisations in the academic debate. There is no universal approach to the language revitalisation efforts, nor there is one effective scenario of halting the processes leading to the language death. Because of that even people deeply committed to the revitalisation cause sometimes face doubts about their actions. Arguments supporting the struggle to protect endangered languages

\footnotetext{
${ }^{2}$ There are, however, some distinguished academics, such as Salikoko S. Mufwene, critical towards the most popular interpretations of the ecolinguistic discourse (eg. Mufwene, 2017).

${ }^{3}$ What is lost is not only an important constituent of minority culture and identity but also tangible information such as cognitive and neurolinguistic data or traditional ecological knowledge.
} 
are constructed on both rationalistic and idealistic premises, but most of them can be questioned in one way or the other. Lists of basic arguments for preserving language diversity can be found in different sources (eg. Crystal, 2000, pp. 27-67; Harrison, 2007, pp. 15-19). Because of that, instead of reiterating them and championing the cause of linguistic diversity, I would like to use a "double negative" approach by stating the most common objections and assessing their validity. They will be discussed not to discourage minority researchers, but rather to help them deal with their own doubts about language revitalisation.

Such a short analysis can be beneficial in several ways. The first one is the most practical: based on a list of counterarguments one can create a frequently-asked-questions style manual for answering them. While working with the local authorities or the communities themselves it is helpful to have concrete answers and examples ready to counter the antiminority attitudes, often stemming from a biased approach which can be changed. Contacts with the authorities often show that communication problems arise even when speaking with people supporting revitalisation. It may be surprisingly hard to find a common ground between academics used to modern constructivist approaches in social sciences (such as Frederik Barth's Ethnic groups and boundaries; Barth, 1969) and people often expecting a decisive "scientific" opinion on a subject that is far from being black and white (as the differences between a language and a dialect etc.).

The second benefit may be identifying the valid objections. While many different counterarguments can be easily rejected by using real data and proper evidence, there are certain areas of interest where it is not possible. In such cases, the strongest arguments for getting involved in the language maintenance are often based on claiming the moral high-ground, which cannot be universally accepted (cf. Cameron, 2007). The final benefit is purely theoretical - while we all face doubts about the impact of the academic involvement in the linguistic communities, various seminars, conferences and workshops tend to treat the subject as something universally settled and obvious (hence the emphasis on individual case studies and less theoretical debate). However, as it is often the case in social sciences, there are no black and white answers. We cannot generalise and claim that revitalisation is always the right choice and language death - however sad for the linguist - has a universally negative outcome for the community of its users. Many ethical questions are and must be - left without a concrete answer, yet they are worth asking just to stimulate the discussion and avoid "preaching to the choir" attitude. 


\section{Typology of arguments}

The following four subsections are each devoted to one category of anti-revitalisation argument and contain a quote from its proponent, its short description and possible responses to the stated problem. The proposed groups of arguments are those based on the concept of linguistic natural selection (1), the allegedly peaceful death of a language (2), the reductionist approach to the language (3) and socio-political factors (4). The list is not exhaustive and can be further expanded (perhaps for the purpose of a proposed FAQ manual) by splitting larger groups of arguments into more specific cases or by adding new arguments, perhaps already stated by some authors but overlooked in this paper.

\subsection{Language, red in tooth and claw - the argument of natural selection}

The extinction of an animal in a modern world is almost never because of natural selection. it is because of actions of man. The extinction of a language however still is natural selection. If it dies out it is because humans no longer need it to communicate. As long as they do, they will. (Mitchell, 2010)

The above quote from a British comedian and columnist states perhaps the most common argument in favour of letting the endangered languages vanish. The whole video, ridiculing the efforts to promote the Gaelic (Gàidhlig) language of Scotland and the Cornish (Kernowek) language revival, sparked an uproar in the Scottish social media. Mitchell's opinion suggests that language death, being a natural process, should not be treated as a real problem and therefore receive any public funding. While this common-sense approach may at first sound convincing (especially due to its connection to the oft-cited comparisons between endangered languages and biological species), it is based on two false premises.

The argument openly denies the man-made character of the ongoing language extinction processes in the modern world. What it fails to recognise is that it is exactly the actions of men - be it open discrimination or less obvious social pressure - that forces minority language users to abandon their ancestral tongues. If the reason for language change is man-made (and often caused intentionally), then the "unnatural" attention of both activists and scholars (resulting in public funding) may be seen as a valid response to the problem, especially from an ethical standpoint.

The second false premise is not explicitly stated, but can be derived from the very notion of "linguistic natural selection". The quote suggests that some languages are fitter, 
i.e. better suited for the modern world and its changing environments. The fitness factor, however, is not an intrinsically linguistic one because - as stated by Morris Swadesh in 1948 "There are no such things as inherently weak languages that are by nature incapable of surviving changed social conditions" (Swadesh, 1948, p. 234). No language is by default better than the other, but some have much bigger potential due to their extralinguistic strength - cultural and political impact, the proverbial "army and navy" (Weinreich, 1945, p. 13). The fact that in a certain moment some language develops and spreads quicker while other loses its speaker basis is dependent almost exclusively on the economic and political power of the communities involved. The larger the speaker basis and the higher the status of a language, the faster it develops further in a kind of a snowball effect - claiming new loanwords by contact with other languages, reacting to new challenges and thus adapting to the new contexts. This process can be exemplified by English as an international language - it is not better fitted for the role than related West Germanic languages such as German or Dutch (or any other language for that matter), but its status is built on the global Anglo-American influence started in the colonial period. Such processes are not an example of natural selection per se, but a situation more comparable with a free-market competition. The quality of the goods - the capacity of the language itself - is not the main factor establishing its popularity, but is heavily influenced by external elements such as branding and advertising. In this case those external factors are the prestige of a language and its ability to function in different contexts, resulting not from some deep structures of the language but acquired in socio-cultural development of the community.

\subsection{All things pass - the argument of peaceful death}

More often than not, the end of a language is not sudden but gradual (...). The terms "life" and "death" seem of little use in such a setting, for they cannot but suggest a distorted image of the time of language, which is not segmented but continuous and in which emergence and decay cannot be isolated as distinct moments. (Heller-Roazen, 2008, pp. 67-71)

Another common argument is based on the supposed graduality and peaceful character of language death. It states that obsolescence is an inevitable fate of any language and as different languages have died in the past, new languages always took their place.

\footnotetext{
4 "A language is a dialect with an army and navy" is a quote popularised by Max Weinreich in the 1940's. Its authorship is debated as some scholars are said to have used it earlier.
} 
While it is a true notion, it often confuses two language death situations, as seen in Daniel Heller-Roazen's Echolalias. The essays "Dead Ends" (Heller-Roazen, 2008, pp. 53-66) and "Thresholds" (Heller-Roazen, 2008, pp.67-75) comment on the moral panic surrounding language extinction by comparing the famous extinction examples of languages such as Ubykh (crowded out by stronger Turkish language and culture) with language change in ancient languages resulting in the creation of new closely related idioms. It is exemplified by the "death" of Latin and the evolution of Romance languages. Such kind of language change indeed means that one idiom gradually evolves into another without a single noticeable breaking point, until the older form is no longer used. The author then uses it to argue that the very concept of "language death" is unscientific, because it cannot be properly defined and traced. This, however, is irrelevant when it comes to endangered languages. What was also overlooked by the author but useful in this context is the differentiation between an extinct language (without any speakers and living descendants) and a dead one (without a native community).

While we can ponder if the language dies with its last user or long before it, when it loses its communicative function, particular languages do die out and it definitely is an issue to consider and not only a matter of "belief" as Heller-Roazen puts it (Heller-Roazen, 2008, p. 58). The case of gradual change within one language, over centuries making older versions unintelligible for the current speakers, or its split into new descendant languages, should not be compared with situations in which one language is replaced by another in a short period of time.

By mentioning the graduality of language abandonment Heller-Roazen attepts to describe this process as natural and painless for the language users themselves. While the very term "gradual death" appears in studies concerning language endangerment, it applies to only one kind of language death situation (L. Campbell \& Muntzel, 1989, pp. 181-186). Compared to the "radical" kind mentioned in the same paper, it does not contain any overt persecution, but the implied graduality does not mean lack of external pressure. While discrimination may take softer forms, it still forces the younger generations to switch to the dominant language in search of better life opportunities, education and career choices. In fact, one may argue that the border between "radical" and "gradual" language death situation is purely arbitrary because the status and position of a language can be diminished even without an overt anti-minority policy. Perhaps the only truly peaceful kind of language death situation is the "bottom-to-top" one, when the minority language retains most of its cultural status while losing the communicative function and viability. 


\subsection{It is only a language, right? - the reductionist arguments}

The world is remarkably resilient in preservation of diversity; different cultures are always dying while new ones arise. They may not be based on ethnicity or language, but the differences remain. (Ladefoged, 1992, p. 810)

The next group consists of two versions of a similar argument. Both are based on a reductionist approach towards a language, failing to recognise its multi-dimensional nature. The described opinions treat the language as merely a tool, serving the purpose of either propagating the culture or communicating with other people. As both can be achieved by means of any other language, the death of a particular idiom does not leave a void.

The first version of this argument states, that language is merely a cultural heirloom and if the cultural value can be preserved by other means, losing of a language does not necessarily create an important difference for the community involved. This, however, does not recognise the biological foundations of a language. As a way of creating culture, not something made by one, it is far more deeply rooted in the minds of its users than any other cultural form. It is internalised much deeper than any other medium of transferring the cultural identity and present in every social interaction, unlike other signs of identity limited to certain situations (traditional costume, ceremonies etc.). The second version of this argument claims that any language is just the communication tool that can be replaced at any time by any other language fulfilling the same purpose. It does not acknowledge the cultural and identity-building aspects of a language. Being forced to abandon one's native language may leave the community scarred for generations to come, by severing the connection to the past and the cultural heritage $\mathrm{e}^{5}$.

However, if the trauma stems mainly from the experienced repression and discrimination, perhaps it should not be an important issue in cases of a truly gradual language shift. Such cases are brought up by the opponents of language revitalisation, and while it is theoretically possible for the community to lose their ancestral tongue without damage being inflicted to their society, many examples are based on a simplified or misinformed view. This is a case of another proponent of the reductionist argument, British writer Kenan Malik. In his vitriolic essay fittingly entitled Let them die not only does he openly declare, that "A language spoken by one person, or even a few hundred, is not a language at all.

\footnotetext{
${ }^{5}$ The correlation between linguistic rights and health - both physical and psychological - of minority language users is currently researched and becomes still more important argument supporting language reviatalisation efforts (see Mclvor, Napoleon, \& Dickie, 2009).
} 
It is a private conceit, like a child's secret code", effectively stripping minority languages from all meaning and function apart from the strictly communicative one. He also tries to validate this claim with a concrete example, bringing up the story of Marie Smith Jones (Udach' Kuqax*a'a'ch), the last chief of the Eyak Nation in Alaska:

"Eighty-one year old Marie Smith Jones is the last living speaker of Eyak, an Alaskan language. When she dies, so will her language. (...) The reason that Eyak will soon be extinct is not because Marie Smith Jones has been denied her rights, but because no one else wants to, or is capable of, speaking the language." (Malik, 2000)

The passage quoted above appears to combine all the arguments described up to that point. Not only is the death of Eyak gradual (speakers allegedly have not been denied their rights), and the language dies because it lost its communicative function. While such a standpoint may look convincing, it is in fact deeply ignorant in regard to the deeper reasons of language obsolescence. Even if Marie Smith Jones as the last speaker has received the support of linguists and media interest, she has been raised in an environment where bilingualism was scorned upon and the Eyak people had long and tragic history of contact with European settlers in the past. As novel diseases and industrial scale fishing drastically changed the demographic situation in the Southcentral Alaska by the end of the $19^{\text {th }}$ century (L. J. Campbell, 1996), the death of Eyak language cannot be described as peaceful and gradual example of "natural selection".

\subsection{No simple answers - the arguments based on socio-political factors}

But most languages die out, not because they are suppressed, but because native speakers yearn for a better life. Speaking a language such as English, French or Spanish, and discarding traditional habits, can open up new worlds and is often a ticket to modernity. (Malik, 2000)

The final quote from Malik's essay tackles what in my opinion remains the most problematic issue regarding minority languages. While he again constructs a simplified argument by describing a binary choice between backward "tradition" and desired "modernity", the core of his thought stays valid. Minority groups speaking endangered languages are usually underfunded and cannot provide higher levels of education in their language. People belonging to those groups may be tempted to choose a more prestigious language granting them access to better career choices and higher quality of life. And while bilingualism 
or trilingualism is in many cases perfectly possible ${ }^{6}$, it requires the will of the speakers and much more effort in their everyday lives than, for example, performing some traditional ceremony or organising an event once a few months. As philosopher Rebecca Roach puts it in her essay, "(...) we can't preserve a minority language by paying people to carry out maintenance. Instead, we must get people to make the language a big part of their lives, which is necessary if they are to become competent speakers" (Roache, 2017). While we can encourage people to preserve their languages by helping raise its status and general attractiveness, forcing anyone to hold on to it at all costs seems paternalistic at best (and colonial at worst).

Apart from perpetuating inequality, the minority language defenders are accused of political involvement, especially in the post-colonial context, where the support for local groups may undermine the efforts of still young nation-states (Ladefoged, 1992, p. 810). This implies the possibility of politically transparent research, which is unlikely in most situations as even the decision not to get involved remains in its core a political one (Dorian, 1993, pp.575-576).

In a perfect world, preserving each and every endangered language is not at odds with allowing its users to participate on equal rights in the life of the ethnic and linguistic majority. Unfortunately, the communities and the linguists involved in revitalisation or documentation efforts must work and plan within the confines of the individual situation. If protecting the language means perpetuating the differences leading to discrimination and repression, the ethical choice may be to let the language become obsolete and protect the well-being of its former users. While the language itself should be documented in a best possible way, it is not the abstract grammar, vocabulary and syntax to be preserved at all costs, but the individual people whose safety may be in danger.

\section{Final thoughts - individual or universal approach?}

As can be seen in the quoted passages from opinion pieces, the opponents of language revitalisation tend to make generalisations and oversimplifications, quoting anecdotal evidence from different cultures and places to back up their claims. The same problem appears often in the works supporting the rival ecolinguistic approach. The more "tangible" rational

\footnotetext{
${ }^{6}$ The notion of choosing only one language is of course rooted in the Western ideas of identity as in many parts of the world multilingualism is a normal state of being (Batibo, 2005, pp. 16-19). The cognitive and developmental benefits of bilingualism are also known and researched for a long time (cf. lanco-Worrall, 1972, more recently Bialystok, Craik, \& Luk, 2012).
} 
arguments in favour of language preservation are based mainly on the examples of the most unique languages from exotic environments (Ahearn, 2011, pp. 247-250). The objective reason why endangered languages are worth saving seems to lie in the traditional ecological knowledge encoded within, unusual rare word order proving unknown cognitive capabilities of the human mind, or some rare phonemes. If we agree with that position, many European minority languages, often closely related to their majority neighbours, may not be equally important for science as indigenous languages of Africa, America, Asia and Oceania.

How different is the traditional knowledge of Lusatian Sorbs form their German, Polish or Czech neighbours? How big differences in a linguistic worldview can exist between closely related languages from the same genetic branch, such as Dutch and Frisian? While I believe that every language in itself is valuable and worth the scientific interest, at the same time I feel that not every language death means an equally profound loss for the humanity. Using only the rational arguments we may inevitably reach the conclusion, that some languages (isolates, usually the most remote ones) are in fact more worthy of saving than the others. If it is true, then the only truly universal arguments in favour of language revitalisation are the ethical ones, at the same time being the most subjective ${ }^{8}$. In fact, the general decision whether to stay a "botanist" and watch as languages fall into disuse or become a "gardener" and get involved even in the smallest extent, is a non-rational choice, most of the minority scholars have already made. The balance of positives and negatives in each individual case, however, may sometimes lead us to entertain the possibility that letting a particular language go may be a viable option.

Speaking of endangered languages in general leads to another problem. However similar the mechanisms of repression or the history of language obsolescence in various places may be, there are important differences between them. I argue that there are at least two models of minority situations and corresponding policies towards them, which can be described as exclusive and inclusive intolerance:

The first model applies to the post-colonial context (in the broadest sense, including the internal colonisation) in which the endangered language belonged to the indigenous population, ethnically and linguistically distinct from the colonisers. Those differences were

\footnotetext{
${ }^{7}$ Such as hotspots of linguistic diversity described in Harrison, 2007, pp. 10-13.

${ }^{8}$ This in a way corresponds with three pro-revitalisation arguments mentioned in a viral video of an interview with Israeli linguist Ghil'ad Zuckermann "Why Revive a Dead Language?"(Babbel, 2018). Zuckermann mentions ethical, aesthetic and utilitarian reasons. The first two groups are clearly subjective, and even the utilitarian ones are seen from an ethical standpoint, as they are concentrated around the well-being of people belonging to once oppressed linguistic groups.
} 
recognised by the dominant group but treated as evidence of the inferior status (lower race, barbaric culture, primitive language etc.). The minority was denied their rights exactly because they were considered different and forcibly excluded from the majority society.

The second situation is typical for some European minorities, whose languages are closely related to the languages of the dominant group or another major language in the region (creating a kind of Ausbausprache and Dachsprache tension, see Kloss, 1967). Without regard to the identity declared by the minority language users, they are forcibly included into the larger group and denied special rights because they are considered "the same" as the dominant population. One of such examples is the situation of Silesian in Poland. In the 2011 census, almost 850.000 people declared Silesian identity, thus becoming the largest ethnic minority in the country (with more than 500.000 people declaring Silesian as their language). The Polish government, however, does not acknowledge their existence as anything more than a regional group within the Polish nation and Silesian is considered a dialect of Polish?

Such "inclusive" intolerance may be supported by some linguists used to prescriptive approach. They tend to determine the status of a linguistic variation based on tradition and established dialectal divisions, not acknowledging the change happening within the speech community itself, and the fact that linguistic identity not always corresponds with measurable linguistic differences. Newly established language is considered a broken variety of the "proper" dominant language and as such its "birth" is not acknowledged.

Perhaps, in the end, all linguists working on the topic of minorities are gardeners, and the only difference lies in their idea of a perfect garden. Some prefer unchanging and strictly planned jardin à la française with strong regulatory bodies, others - a more natural English park, where the plants are encouraged to grow wild.

\section{Bibliography}

Ahearn, L. M. (2011). Living language: An introduction to linguistic anthropology. Chichester: Wiley-Blackwell. https://doi.org/10.1002/9781444340563

Babbel. (2018). Why revive a dead language?: Interview with Prof. Ghil'ad Zuckermann [Youtube video]. Retrieved March 20, 2018, from https://www.youtube.com/watch?v=izVGZRqciTY

\footnotetext{
${ }^{9}$ Other examples include Wymysorys (struggling for official recognition in the Polish parliament and still considered by some of its opponents a German dialect) and different Rusyn varieties in Central Europe (classified by some scholars as a dialect group of Ukrainian language, a view supported by some subgroups within the Rusyn community).
} 
Barth, F. (1969). Ethnic groups and boundaries: The social organization of culture difference. Boston, MA: Little, Brown and Co.

Batibo, H. M. (2005). Language decline and death in Africa. Clevedon: Multilingual Matters.

Bialystok, E., Craik, I. M., \& Luk, G. (2012). Bilingualism: Consequences for the mind and brain. Trends in Cognitive Sciences, 16(4), 240-250. https://doi.org/10.1016/j.tics.2012.03.001

Cameron, D. (2007). Language endangerment and verbal hygiene: History, morality, and politics. In A. Duchêne \& M. Heller (Eds.), Discourses of endangerment (pp. 268-285). London: Continuum.

Campbell, L. J. (1996). Native cultures in Alaska. Alaska Geographic, 23(2), 70-73.

Campbell, L., \& Muntzel, M. (1989). The structural consequences of language death. In N. Dorian (Ed.), Investigating obsolescence: Studies in language contraction and death (pp. 181-196). Cambridge: Cambridge University Press. (Studies in the Social and Cultural Foundations of Language, 7). https://doi.org/10.1017/CBO9780511620997.016

Crystal, D. (2000). Language death. Cambridge: Cambridge University Press. https://doi.org/10.1017/ CBO9781139106856

Dorian, N. C. (1993). A response to Ladefoged's other view of endangered languages. Language, 69(3), 575-579. https://doi.org/10.2307/416699

Harrison, K. D. (2007). When languages die: The extinction of the world's languages and the erosion of human knowledge. Oxford: Oxford University Press. https://doi.org/10.1093/acprof :oso/9780195181920.001.0001

Heller, M., \& Duchêne, A. (2007). Discourses of endangerment: Sociolinguistics, globalization and social order. In A. Duchêne \& M. Heller (Eds.), Discourses of endangerment (pp. 1-13). London: Continuum.

Heller-Roazen, D. (2008). Echolalias: On the forgetting of language. New York, NY: Zone Books. lanco-Worrall, A. D. (1972). Bilingualism and Cognitive Development, Child Development, 43 (4), 1390-1400. doi: 10.2307/1127524

Kloss, H. (1967). 'Abstand languages' and 'ausbau languages'. Anthropological Linguistics, 9(7), 29-41.

Ladefoged, P. (1992). Another view of endangered languages. Language, 68(4), 809-811. https:// doi.org/10.2307/416854

Lüpke, F. (2018). Supporting vital repertoires, not revitalizing languages. In L. Hinton., L. Huss, \& G. Roche (Eds.), Routledge handbook of language revitalization (pp. 475-484). New York, NY: Routledge.

Maffi, L. (2005). Linguistic, cultural and biological diversity. Annual Reviev of Anthropology, 34, 599-617. https://doi.org/10.1146/annurev.anthro.34.081804.120437

Malik, K. (2000). Let them die. Retrieved March 20, 2018, from http://www.kenanmalik.com/ essays/die.html (Originally published in $57^{\text {th }}$ issue of Prospect magazine, November 2000).

Mclvor, O., Napoleon, A., \& Dickie, K. (2009). Language and culture as protective factors for at-risk communities. Journal of Aboriginal Health, 5(1), 6-25. https://doi.org/10.18357/ijih51200912327 
Mitchell, D. (2010). The Gaelic language [Youtube video in the series David Mitchell's Soapbox]. Retrieved March 20, 2018, from https://www.youtube.com/watch?v=OvIQXPNwrqo

Mufwene, S. S. (2017). Language vitality: The weak theoretical underpinnings of what can be an exciting research area. Language, 93(4), 202-223. https://doi.org/10.1353/lan.2017.0065

Newman, P. (1998). We has seen the enemy and it is us: The endangered languages issue as a hopeless cause. Studies in the Linguistic Sciences, 28(2), 11-20.

Roache, R. (2017). The death of languages. Retrieved March 20, 2018, from https://aeon.co/ essays/should-endangered-languages-be-preserved-and-at-what-cost

Swadesh, M. (1948). Sociologic notes on obsolescent languages. International Journal of American Linguistics, 14(4), 226-235. https://doi.org/10.1086/464009

Weinreich, M. (1945). Der YIVO un di problemen fun undzer tsayt. YIVO Bleter, 25(1), 3-18.

\section{The dilemmas of a gardener: discussing the arguments against language revitalisation}

\section{Abstract}

The article restates and comments on the most common arguments against language maintenance and revitalisation found in popular texts and discussion articles from academic journals. By grouping them and assessing their validity we may better see which objections must be faced and which are based on easily disproven misconceptions. The described counterarguments are divided into four groups and based on the ideas of linguistic natural selection, peaceful death of a language, reductionist approach to the language, and sociopolitical factors. Most of them seem to use overgeneralisations and fail to recognise the deeper causes behind language obsolescence. The most valid, depending on the individual situation, are the arguments based on socio-political reasons. Generalisations and essentialising discourse, however, are also found in the opinions of the proponents of language maintenance. The author claims that the truly universal arguments in favour of language maintenance are in fact only those based on the subjective convictions of the people involved, as all rational arguments can be undermined in certain contexts.

\section{Keywords:}

endangered languages, endangerment discourse, engaged linguistics, language death, language revitalisation 


\section{Dylematy ogrodnika: dyskusja z argumentami przeciwko rewitalizacji językowej}

\section{Abstrakt}

W artykule streszczone i skomentowane zostały najczęstsze argumenty przeciwko rewitalizacji języków zagrożonych obecne w mediach niespecjalistycznych i czasopismach naukowych. Usystematyzowanie i analiza tych opinii pozwala stwierdzić, które zastrzeżenia oparte są na błędnych założeniach i łatwe do zakwestionowania, a które należy traktować jako rzeczywiste wyzwanie. Kontrargumenty, podzielone na cztery główne grupy, opierają się na redukcjonistycznym stosunku do języka, koncepcjach językowego doboru naturalnego i spokojnej śmierci, oraz czynnikach społeczno-politycznych. Większość z nich posługuje się daleko idącą generalizacją i nie bierze pod uwagę głębszych przyczyn wymierania języków. Najbardziej zasadne w konkretnych sytuacjach okazują się zazwyczaj argumenty odwołujące się do kwestii społeczno-politycznych. Ponieważ łatwe do zanegowania tezy, bazujące na uproszczeniach i dyskursie esencjalistycznym, są obecne również w opiniach zwolenników rewitalizacji, jedynymi prawdziwie uniwersalnymi argumentami na rzecz lingwistyki zaangażowanej wydają się być argumenty idealistyczne, oparte na subiektywnych przekonaniach konkretnych osób.

\section{Słowa kluczowe:}

języki zagrożone, dyskurs zagrożenia, lingwistyka zaangażowana, śmierć języka, rewitalizacja języka

\section{Citation:}

Mętrak, M. (2018). The dilemmas of a gardener: discussing the arguments against language revitalisation. Adeptus, 2018(11). https://doi.org/10.11649/a.1724 